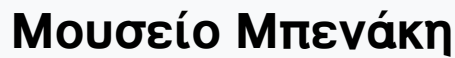

A Singular Antiquity: Archaeology and Hellenic Identity in Twentieth-Century Greece

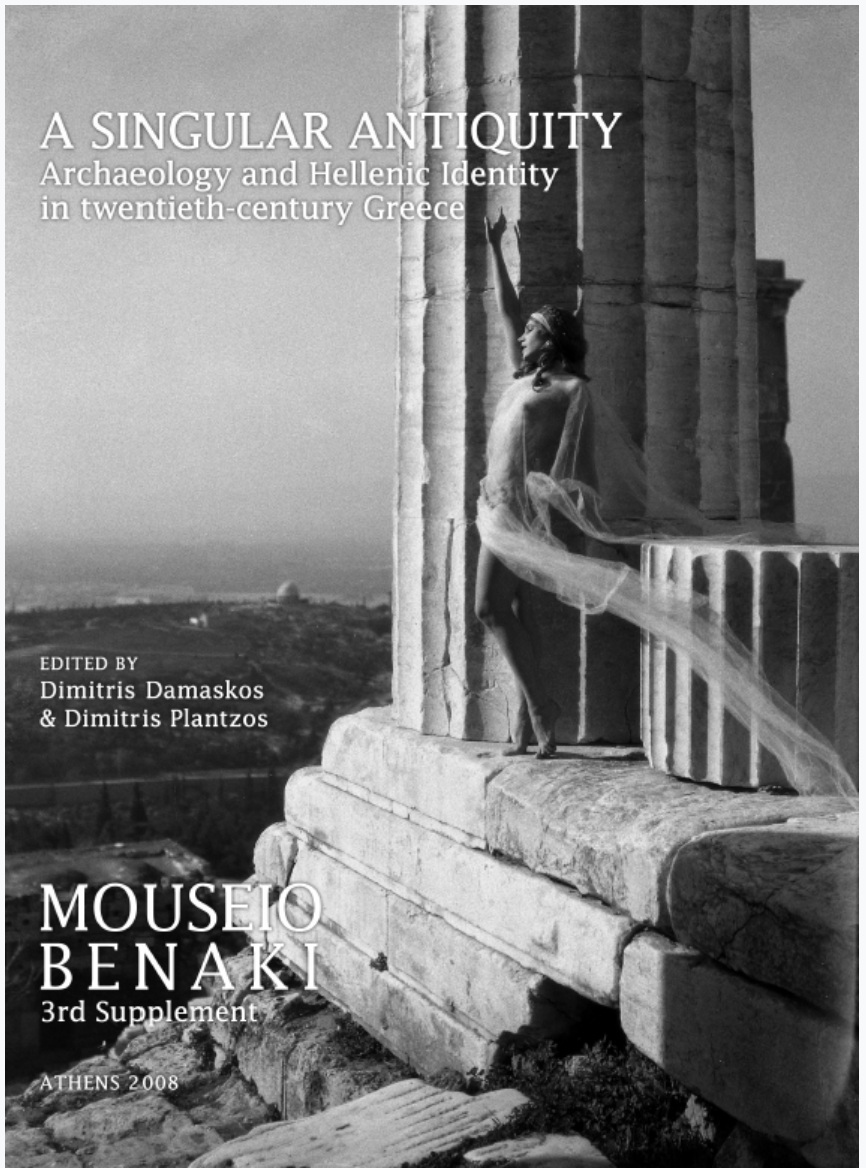

\section{Greek legislation concerning the international movement of antiquities and its ideological and political dimensions}

Daphne Voudouri

doi: 10.12681/benaki.17982

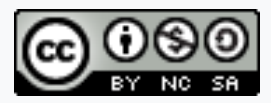

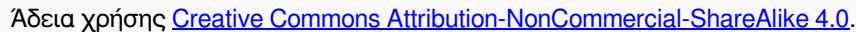

\section{Bıß入ıоррачıкń avaчopá:}

Voudouri, D. (2008). Greek legislation concerning the international movement of antiquities and its ideological and

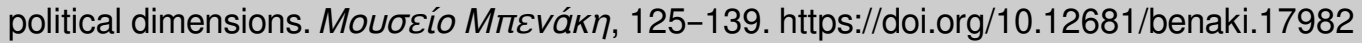




\section{Greek legislation concerning the international movement of antiquities and its ideological and political dimensions}

THIS PAPER EXAMINES the main lines of the Greek legislation on antiquities with regard to their international movement, in the course of its history and in the context of the relevant international experience and reflection. At the same time, it attempts to shed light upon the ideological and political dimensions of this issue, which is connected with the perception of ancient monuments as national symbols and sacred heirlooms, has caused intense disputes, and acquired added interest in the global environment.

Within the chronological confines established by the title of the present volume, this analysis starts with Law 2646/1899 'On antiquities,', and concludes with Law $3028 / 2002$ 'On the protection of antiquities and cultural heritage in general', ${ }^{2}$ currently in force. However, the formation and evolution of the status of the archaeological heritage in Greece cannot be understood without, initially, some account of the first - and early - measures for its legal protection.

Already an object of particular admiration in Europe and in growing demand among foreign travellers, the material remains of ancient Greece played a crucial role in shaping Greek national identity and legitimizing the modern Greek state. The fact that Classical Greece was viewed as the fount of European civilization was 'a symbolic advantage for the modern Greeks, who inevitably laid claim to the exclusive inheritance of the ancient glory. ${ }^{3}$ Thus, when the new state was taking its first steps, and even before its foundation, measures were taken to protect the antiquities, the principal aim being to deter their sale and exportation outside the borders.
Deterring the exportation of antiquities: a primary concern of the fledgling Greek state

The first promptings for the preservation of 'the proofs of our ancestral glory' and the founding of a 'Greek Museum' are attributed to Adamantios Korais, the leading representative of the Modern Greek Enlightenment, who wrote in 1807 that the nation's accusers had to be convinced that 'we neither give away, nor do we sell our ancestral property any more.'

During the War of Independence, among other measures, a decree was issued in 1825 by Papaflessas, Minister of the Interior of the revolutionary government, regarding the collecting and safeguarding of antiquities in schools, on the basis of the following arguments: 'so that, with the passage of time, every school will acquire its own Museum, something which is most necessary for history, for the discovery of the ancient names of cities and places, for a knowledge of the skill of our ancestors, and for the esteem for such things which the wise nations of Europe, who censure us because we give them away or sell them at a low price to their travelers visiting Greece, rightly entertain.'5

The prohibition of the sale and transfer of antiquities outside Greece was introduced in 1827, by a resolution of the Third National Assembly of Troezen. ${ }^{6}$ This special concern was also deeply felt by many of the freedomfighters, as shown by the well-known words of General Makriyannis to soldiers who were preparing to sell two ancient statues to Europeans: 'Even if they were to give you ten thousand thalers, do not allow them to leave your homeland. These are what we fought for'? 
The above mentioned ban was confirmed two years later by the National Assembly of Argos, though, at the same time the Governor was authorized, by way of exception, to permit 'the exportation of fragments only of antiquities, and only when these are sought as contributing to the archaeological research of a scientific establishment of any Government.' ${ }^{8}$ This amendment was adopted on the proposal of Governor Kapodistrias, 'with a view to the greater benefit of the Nation', following pressure from the French, who had asked for finds from the excavations of the Expédition Scientifique de Morée at Olympia. The difficult diplomatic position of the fledgling state is already apparent: on the one hand, it claimed exclusive rights over the antiquities, while, on the other, it sought to avoid displeasing the Great Powers, on whom it was dependent.' It is worth noting moreover that in his proposal Kapodistrias had also identified the possibility of exchanging antiquities with objects from abroad which would be of use to the country. ${ }^{10}$

At the same time, in order to ensure the safeguarding of antiquities within Greece, the first museum was founded as a state museum in 1829 in Aegina. ${ }^{11}$

In 1833, two months after the arrival of King Otto in Greece, in the decree setting up the Secretariat of State for Church Affairs and Public Education, were included among its competences 'the preparation for excavation and discovery of the lost masterpieces of the arts, care for the preservation of those already existing and vigilance to ensure that these are not exported from the State. ${ }^{12}$

The ban on exporting antiquities without a permit, backed up by penal sanctions, which still constitutes one of the foundations of the relevant Greek legislation, was enshrined in the first national archaeological legislation of 1834 , which was pioneering for its time. ${ }^{13}$ More specifically, according to that law, which was adopted by the Regency under the influence of Bavarian Neoclassicism, an export licence was to be granted only in the case of objects which were 'duplicates' of those in the museums (which the law provided the State would establish), of objects legally imported from abroad, or of objects declared to be 'insignificant' or 'surplus. ${ }^{14}$ These were part of a set of measures for the protection of antiquities which was inspired by legislation enacted by the Papal State of Rome in $1820^{15}$ and included, inter alia, a ban of excavating without a permit and an obligation to declare any finds.

Most importantly, at least from a political point of view, the law declared that 'all antiquities within Greece, as works of the ancestors of the Greek people, shall be regarded as national property of all the Greeks in general' (Article 61). This provision expresses the concept of cultural heritage, even if the term was not introduced until much later.

State ownership of antiquities

The law of 1834 recognized nevertheless a right of ownership of antiquities by individuals under certain conditions and within certain limitations. Full and absolute ownership on the part of the state was recognized in the case of antiquities which were to be found on publicly owned land or beneath it, at the bottom of the sea, or in rivers or public streams, lakes or marshes. ${ }^{16}$

This law was replaced by a stricter one in 1899 , since it was considered that, while it had been in force, the markets of Europe had been turned into 'auction-houses for Greek antiquities', in the words of the Minister for Church Affairs and Public Education, Athanasios Eftaxias, ${ }^{17}$ and that there had been a general increase in illicit dealing in antiquities (archaiokapilia), that 'worm gnawing at our national honour', as Eftaxias wrote in a circular on the implementation of the new law of $1899 .{ }^{18}$ This circular begins as follows:

'We Hellenes owe our independence to a large extent to the glorious name and the immortal monuments of art which we have inherited from our ancient ancestors. And just as we have a duty to make every effort at all times to show ourselves worthy of the name which we bear, so in the same way there is a sacred duty incumbent upon us all to regard as sacred heirlooms and to safeguard the antiquities if we wish to prove to the civilized world that it was justly that we became an independent State and that justly are we called Hellenes'.

Thus, through the appropriation of the ideological construct of European superiority that harked back to an idealized Greek antiquity, ${ }^{19}$ the protection of the 'ancestral' works was employed to justify national independence, the national name, and the inclusion of the Greek state in European modernity.

Nevertheless, the state authorities did not overlook the economic value of the antiquities, which 'will turn Greece 
into an object of pilgrimage for all the civilized peoples and will in this way prove not only objects of honour and veneration, but also a source of wealth for our country', as was foreseen in the circular quoted above.

The main innovation of Law 2646/1899 was the establishment of an exclusive right of ownership of the state over all antiquities, movable and immovable, to be found anywhere in Greece, even on private land (Article 1).

The principle of state ownership of antiquities, which is indissolubly bound up with the question of their movement, was also included in Codified Law 5351/1932 'On antiquities ${ }^{20}$ and is also provided for by the current Greek legislation of 2002. Although a similar rule is in force today in many other countries, particularly in 'source countries', it seems that in 1899 it had not been introduced into other national legislations. ${ }^{21}$

The principle of state ownership applies to antiquities dating up to 1453 , the year of the Fall of Constantinople. ${ }^{22}$ The law of 1899 included within its field of application objects of 'medieval Hellenism', a term which suggests the adoption of the scheme of Konstantinos Paparrigopoulos' History of the Hellenic Nation and of the new concept of the unbroken continuity of Hellenism from antiquity to the present, with Byzantium, rehabilitated and 'Hellenized', as the mediating link. It is worth pointing out that during the nineteenth century Byzantine monuments, as well as Venetian, Ottoman or other post-classical monuments, were not only neglected but often even destroyed in the interests of 'purifying' the material evidence of the ancient Greek past, ${ }^{23}$ in spite of an explicit mention in the law of 1834 and in a royal decree of 1837 of the protection of medieval remains as well. ${ }^{24}$

Provisions for the disposal of antiquities and resistance to their implementation

The law of 1899 laid down a sui generis right of possession, disposal and sale by individuals of antiquities which had been characterized as 'redundant' or 'surplus' to the requirements of the state museums. ${ }^{25}$ The exporting of antiquities by individuals was also only possible insofar as they were considered 'redundant', while at the same time a tax was imposed on their value. ${ }^{26}$ Legally imported ancient objects were now no longer permitted to be reexported, except following certification of their identity and the issuing of a licence, ${ }^{27}$ in order to combat the illicit movement and smuggling to the West of antiquities coming from 'unredeemed Greece' (e.g. Crete or Cyprus). ${ }^{28}$

In the case of antiquities held in the state museums, there was a provision for their exchange for objects from foreign museums or academic institutions on condition that they had been declared surplus. ${ }^{29}$ It is worth noting that it had also been proposed that it should be possible to sell such objects, but the State Archaeological Service disagreed, while the possibility of ceding them by gift was rejected by Parliament, in order to avoid any pressure in this respect. ${ }^{30}$

This had already been preceded in $1882^{31}$ by fierce and high-level debates in Parliament and disagreements among archaeologists over the implementation of a clause in the Greek-German convention on the excavations at Olympia concerning the ceding, at the discretion of the Greek government, of duplicates or replicas to Germany, a provision which has not been repeated since. ${ }^{32}$

Scope not only for the exchange for other useful objects but also for the sale of antiquities held by the state which were deemed redundant to state museums and smaller collections was provided by a law passed in 1914, amended in 1930 and included in Codified Law 5351/1932 (Article 53).$^{33}$ Proceeds were to be channelled into the Archaeological Fund for the purpose of funding expropriations of archaeological sites, a provision which is connected with others adopted concurrently with the aim of financing archaeological museums and sites more effectively. ${ }^{33}$

As can be seen from the explanatory report on Law $5351 / 1932$, which was signed by Georgios Papandreou as Minister of Education, the legislator started out from the assumption that the total ban on the possession and sale of important antiquities by individuals in the law of 1899 had resulted in the state archaeological museums being overfilled with ancient objects, often of small value or identical to others, thus giving rise to serious problems as regards conservation and display. In addition, it deprived the state 'of valuable assistants in the safeguarding and preservation of antiquities in the state, such as genuine antiquarian collectors'. It also led to the concealment of ancient objects discovered by chance by individuals and their smuggling abroad. Hence this law introduced a series of innovations, such as the right of private persons to possess even important movable antiquities and a special regime for private collectors of and dealers in antiquities. 
There was provision, inter alia, for the exchange of 'multiple' ancient objects in private collections with those of equivalent value from foreign museums. ${ }^{34}$

However, the above provisions concerning the sale of antiquities were never implemented in practice (whereas similar provisions have been applied, for instance, in $\mathrm{Cy}-$ prus), mainly because of the opposition of archaeologists. Nor does it seem that any exchange of ancient objects held by the state ever took place - except once, after a request from the Louvre Museum concerning the exchange of remains from the Sanctuary of Samothrace with fragments of the Victory of Samothrace, by virtue of a special law $(3124 / 1955),{ }^{36}$ because these items could not be characterized as redundant.

The most comprehensive and most often quoted argumentation against the sale of antiquities was given expression by Christos Karouzos in an article in the press in $1948 .{ }^{37}$ In this, he recalls the excavations at Olympia, which had already shown that 'duplicate' ancient objects do not exist, and argues that for the science of archaeology there are no such things as 'redundant' antiquities, reaching the conclusion that 'no ancient object, however shattered, however poor in quality which goes into the Museum is finally and irrevocably insignificant, none is surplus, none is for throwing away - that is, for sale'. The change in the archaeological approach from that of the nineteenth century is apparent: then, for example, 'shapeless pieces of sculpture, fragments of clay figurines and pottery, vessels of common pattern and forms [...] or with degenerated forms' are cited by way of indication as ancient objects 'of no scientific value' in a decree of 1899 , issued in implementation of Law $2646 .^{38}$

In his article, Karouzos stresses moreover that, apart from the harm to science, 'the sale of the antiquities [...] will cheapen the State itself, which will pollute its museums with corner-shops of antiquities; if the State thus debases definitively the moral nature of the antiquities and of the Museum, transforming them from the inviolable sacred objects which until now it has proclaimed them to be into marketable goods for trade'. However, this eminent archaeologist did not condemn in principle the exchange of antiquities, quoting as a model the provisions of the law of 1899, nor did he object to donations in exceptional circumstances.

Recalling Karouzos, or even Papaflessas and Makriyannis, the majority of Greek archaeologists, particularly
- though not exclusively - in the Ministry of Culture, seem even today to be opposed not only to the sale but also to the exchange or donation of antiquities, even for educational purposes. The condemnation of a proposal along these lines from one of their distinguished colleagues at a conference on the draft new archaeological law in 1998 is indicative. ${ }^{39}$

It is, then, no surprise that Law 3028/2002 made no provision for any other possibility of disposal of movable antiquities in the possession of the state apart from exchange, under certain terms and conditions (among them, the object's lack of any 'particular significance for the country's cultural heritage'), for cultural objects of foreign origin. ${ }^{40}$ And this in spite of the fact that in the meantime increasing numbers of finds, particularly from rescue excavations (given the scale and frequency of major construction projects carried out in recent decades), are piling up in the storerooms of the museums and Ephorates of Antiquities. Thus the legislator basically returned to the regulation of 1899, while at the same time complying with the Recommendation of UNESCO of 26 November 1976 concerning the international exchange of cultural property.

As has already been mentioned, the new law retains the principle of state ownership of antiquities dating from up to 1453 , which it also characterizes as extra commercium, while it provides a stricter regime than that of the 1932 legislation regarding their possesion by private persons. ${ }^{41}$

It is, nevertheless, instructive that the provision of the new law which concerns the exchange and loan of ancient monuments (Article 25) is the one which met with the most objections from the Association of Greek Archaeologists ${ }^{42}$ and Members of Parliament of various parties. ${ }^{43}$ In the same direction, Vasileios Petrakos, General Secretary of the Athens Archaeological Society, in an article written in 2003, having criticized the legislative provision in question, stressed that: 'For scholarship, and particularly Greek scholarship, all [antiquities] are important and are the archive of the ancient Greek world. It is not possible, rationally, for any of its content to be given as a loan, to be sold, or exchanged'. ${ }^{44}$

Temporary exportation of antiquities for exhibitions: regulation, practice, disputes

A first mention of the loan of antiquities is to be found in 
an enactment of 1922, supplemented in 1926, which permitted the temporary exportation to Sweden of the finds from the excavations at Asine by the Swedish Archaeological Mission, for assembly, study and publication. ${ }^{45}$ There was also a special provision in the law setting up the Benaki Museum in 1930 on the loan of its objects for inclusion in exhibitions abroad, as well as on the disposal of duplicates belonging to the museum, on an exchange basis or otherwise. ${ }^{46}$

Although the codification of 1932 provided for the possibility of exporting antiquities in the possession of individuals following the issuing of a licence, ${ }^{47}$ it prohibited in principle the export of finds from excavations, which could be exported only after complete examination and publication of the excavation and if they were regarded as redundant to the state's museums (Article 45).

In an express deviation from this provision, Law 654/ $1977^{48}$ made possible the temporary exporting of ancient objects for exhibitions in museums abroad, by a decision of the Council of Ministers, ${ }^{49}$ on the basis of a - simple - opinion of the supreme collective organ for the administration of antiquities, the Archaeological Council.

Up to that point, original Greek antiquities had been sent abroad only under the Metaxas dictatorship ${ }^{50}$ and under the military junta. ${ }^{51}$ However, many unsuccessful requests had been submitted on earlier occasions, but had met with grave objections on the part of the archaeologists..$^{52}$ It is worth citing some typical examples of attitudes in this respect.

Antonios Keramopoulos, commenting in 1924 on a proposal from the President of the Refugee Relief Committee, Henry Morgenthau, for the exhibiting of the Hermes by Praxiteles in America and Europe to cover the refugee loan, wrote that 'in this way we shall prove unworthy of the heritage of our ancestors if we manipulate the antiquities for petty gain'. ${ }^{53}$ Christos Karouzos, arguing in 1952 against granting a similar request from the Metropolitan Museum of Art in New York, concluded that: 'There will not be found even today a Greek archaeologist who is ready to forget his debt to History as a guardian of a unique heritage and to accompany, against his awakened conscience, such an exhibition of the sacred things of the Nation outside the borders of Greece like a vociferous tout'. ${ }^{54}$

The Archaeological Council also rejected a request for the sending of the Hermes by Praxiteles to New York ${ }^{55}$ in
1963 because it regarded it is a problem for Greece 'for it to hawk about at trade fairs the holy and sacred things of the national heritage, with all the attendant dangers, in order to collect dollars', noting, however, at the same time that such a practice would militate against tourism in Greece. In rebutting the argument that a precedent had been set by the sending of Leonardo's Mona Lisa and Michelangelo's Pietà abroad for exhibitions, it went so far as to maintain that 'ancient Greek works have, and only they have, the special character of literally a unicum, which is not the case as a rule with works of modern art'.

The 1977 law was adopted following objections to a request for the dispatch of a large number of exceptionally important antiquities for exhibition at, once again, the Metropolitan Museum in New York. The explanatory report invoked the need to promote Greece internationally, and the passing of the bill met with sharp criticism from the Opposition. ${ }^{56}$

The first implementation of the law, in 1979-80, for the Greek Art of the Aegean Islands exhibition, first at the Louvre and then the Metropolitan, stirred up a storm of protests. Moreover, mainly in Herakleion in Crete, this protest took on the dimensions of social and political revolt, and led to the Minoan antiquities being excluded from the dispatch. The protestors inveighed both against government policy and the United States (the destination of the antiquities) and, in their turn, employed the official rhetoric about the 'uniqueness' and 'superiority' of Greek antiquities. ${ }^{57}$

This was followed by a large number of temporary exportations of antiquities (including Byzantine artefacts) with the prior agreement of the Archaeological Council, which in a number of instances delivered a negative opinion on the loan of specific items, without, however, disagreeing in principle. In any case, large-scale social reactions, like those of 1979, were not sparked off, although there was, and is, no shortage of opponents to the idea of antiquities travelling abroad in general, who invoke patriotic or even nationalistic arguments. ${ }^{58}$

It is worth pointing out that displays of patriotism were not limited to any one side in the debate, since the sending of antiquities abroad for exhibition $s^{59}$ had - particularly in the early years - and still has the declared aim of promoting national identity and continuity, particularly wherever the Greekness of Cyprus, ${ }^{60}$ the Aegean, ${ }^{61}$ or Macedonia, ${ }^{62}$ or the perception of Greece as the cradle of European 
civilization ${ }^{63}$ was thought to be in dispute. In recent years, however, the promotion of 'national issues' stricto sensu (in which we must include, of course, the Olympic Games) ${ }^{64}$ has not been the exclusive objective. Such exhibitions aimed also to the promotion of issues of broader national interest, of a political, economic or cultural nature, such as improving the country's international relations, attracting foreign tourists and investors, or supporting classical studies abroad. In any case, it is worth investigating further what approach to ancient Greek culture and what image of national identity were projected by the various archaeological exhibitions held abroad, ${ }^{65}$ to what extent these were adapted to the particularities of the public to whom they were addressed, and what kind of reception they had.

The current status of loans of antiquities abroad

The provisions of Article 25 of Law 3028/2002 on the loan of movable ancient - or modern - monuments which belong to the state and are in its possession provoked the strongest objections to the bill for the new law, as has been pointed out above. These objections led to the final text being amended in the interests of greater strictness, with restrictive clauses which perhaps tend to make it 'suffocating', as the Minister of Culture, Evangelos Venizelos, observed in Parliament. ${ }^{66} \mathrm{He}$ nevertheless adopted most of the amendments, with the exception of that on the avoidance of long-term loans, invoking a similar proposal of the Greek side concerning the Parthenon Marbles, the return of which is, of course, considered to be a major 'national issue'.

Thus, the reference to loans for research purposes was removed, while terms were added which could create problems in their implementation if strictly interpreted, such as the lending of only 'published' ancient objects (given that finds from excavations, unfortunately, usually remain unpublished), or the condition of reciprocity for lending to museums. Loans are permitted only in exceptional cases, for a period which may not exceed five years, though renewable, for exhibition or educational purposes; in the latter case, provided that the monuments are not of particular significance for the country's cultural heritage. ${ }^{67}$

Difficulties are also likely to be created by interpreting the above provisions in combination with the related provisions concerning the temporary exportation of monu- ments (Article $34 \S 11$ ). This can be permitted on less strict conditions, not only for exhibition or educational purposes, but also for research, or for their conservation, provided that certain guarantees are given. ${ }^{68}$ Temporary exportation can, however, also involve important monuments, whereas the export of monuments which is permanent or for an indefinite period can be permitted, by way of exception, only if the monuments are of no particular significance for the country's cultural heritage and the unity of important collections is not adversely affected (Article 34 § 2). ${ }^{69}$ The law does not make any reference to 'culturally immovable' ancient monuments (those which should never leave the country) - unlike the administration, which banned the loan of the Marathon Boy by the National Archaeological Museum to the Louvre for the recent Praxiteles exhibition, on the ground that it belonged to a list of such works, thus giving rise to a certain amount of tension with the French side. ${ }^{70}$

The provisions of Law 3028 on loan and exchange are integrated into the framework of various international instruments, legally binding or otherwise, which provide for the facilitation, on certain conditions, of the international movement of cultural objects for exhibitions and for other cultural, educational and scientific purposes, in parallel with the combating of illegal movement of such property. ${ }^{71}$

The temporary exchange of cultural objects, especially for international loan exhibitions, ${ }^{72}$ undoubtedly involves risks - chiefly of destruction, damage or loss - which are a deterrent to the movement of particularly fragile or extremely important objects. There may even be risks of seizure while on exhibition abroad, a risk which has become more acute recently with claims on works looted during the Nazi era. ${ }^{73}$ Furthermore, it has been rendered difficult by the sharp rise in the cost of insurance premiums, mainly to cover the additional risk of terrorist attacks, especially in the aftermath of September 11. Nevertheless, this practice, which does not entail transfer of ownership, is developing widely, as it is considered to increase knowledge, enrich cultural life and inspire mutual respect and appreciation among nations. ${ }^{74}$ It is promoted as a tool of cultural diplomacy $^{75}$ and as a means of facilitating comparative approaches to cultural objects, as well as increasing the prestige, the visitor numbers, and the income of museums.

Loan exhibitions are, however, also used for the legitimation ('laundering') of unprovenanced and possibly 
looted antiquities, ${ }^{76}$ which points up the need for checks on the antiquities included in the same exhibition. On the other hand, loans have taken on added interest lately as a means of reducing clandestine excavations and the illicit trade in antiquities. Such an approach is also encouraged by the international archaeological community, whose interest has been focused - in recent decades - on preventing the destruction of archaeological sites and the consequent loss of the information which can be retrieved from the context of archaeological finds. Loans are therefore promoted as an alternative to acquisition of unprovenanced antiquities by museums in 'market countries'. The same approach, moreover, makes it incumbent on countries rich in antiquities to loan only, or preferably, to museums which have adopted a strict policy of enquiry into the ownership history of any object before its acquisition or its acceptance as a loan.

In addition, loan programmes are used as a kind of concession on the part of source countries for the imposition by market states of import restrictions on archaeological material, in order to reduce incentives for pillage and illicit trade, as provided for in several bilateral agreements, concluded for the implementation of the 1970 UNESCO Convention, between the USA and other countries, including Italy and Cyprus. ${ }^{77}$

In parallel, long-term loans feature in the debate over repatriation of cultural objects, as an alternative to their return or restitution to the country of origin by transfer of title (i.e. a change in their location rather than of their ownership), as the Greek side has proposed in recent years in the case of the Parthenon Marbles. They may also constitute a kind of reward or consolation to the returning institution, as provided for in the recent agreement between the Italian Ministry of Culture and the Metropolitan Museum concerning the return to Italy of the Euphronios Krater and other archaeological items ${ }^{78}$ or as seems to be the case with the agreement signed between the Greek Ministry of Culture and the J. Paul Getty Museum regarding the return of two archaeological objects. ${ }^{79}$

Law 3028/2002 undertakes, in general, to take into account modern approaches and practices concerning the protection of cultural heritage. ${ }^{80}$ So, in the interests of restricting illicit trade, it highlights the provenance of cultural objects and includes, inter alia, an obligation on the part of collectors to declare the provenance of antiquities, ${ }^{81}$ thus plugging a loophole in the previous law. It also makes provision for preventing and prohibiting the traffic in Greece in cultural objects acquired or exported from other countries in violation of their legislation, ${ }^{82}$ and prohibits museums, collectors and antique dealers - the main recipients of cultural property - from acquiring cultural objects suspected of deriving from theft or illegal excavation, or of having been acquired or exported in violation of the legislation of the country of origin. ${ }^{83}$

At the same time, it introduces as an incentive for - licit - importation, and particularly for the repatriation of antiquities to Greece, the reservation of the right of ownership of private persons over these, by way of exception from the principle of state ownership, with parallel provision that illicit traffic should not be favoured. ${ }^{84}$

The Greek case in the broader debate:

cultural nationalism vs. cultural internationalism, or who owns cultural heritage?

From what has been discussed so far, it will be clear that the Greek state is particularly concerned that antiquities should remain within the national territory and those illicitly exported be repatriated. This concern goes back a long way and is accompanied by the rooted conviction that the state, as a collective entity, is in a position to protect these antiquities and manage them better (also bearing in mind that almost all the archaeological museums are state-owned). ${ }^{85}$ There is also a widespread belief - among archaeologists at least - that antiquities do not belong within the logic of the market and that it is not fitting for them to be defiled by being dragged into the arena of trade, a view which is reminiscent of the thinking about national symbols and the 'fetishization of their sanctity' ${ }^{86}$ One could, of course, wonder to what extent this 'purist' attitude is utopian, nowadays, if not wilfully self-deluding, given the dimensions of the tourism industry and of the commercial exploitation of the archaeological heritage for mass consumption in the Greek national economy.

Nevertheless, the answer to the basic question inevitably asked as to whether these practices and attitudes are unique to the Greek case, is negative. As has already been pointed out, a particularity and complicating factor is, certainly, the fact that classical antiquity has been considered the foundation of Western civilization, so that Greece has been described as 'the archetype of stress between local 
and global heritage' ${ }^{87}$ Furthermore, and in conjunction with this, the key position of antiquities in the national consciousness and imagination and the pioneering and strict state control over and legislation on archaeological remains should be viewed as specific to Greece, though the connection of archaeology with nationalism and with the nation-state is not, of course, an exclusively Greek phenomenon. ${ }^{88}$

It is a fact that severe export restrictions and declarations of state ownership of antiquities are also to be encountered in the national legislation of very many other source countries. Moreover, legal prohibitions on the disposal of objects from public or national museum collections are also frequent in market states, ${ }^{89}$ and such arguments are used, for instance, by the British Museum against the return of the Parthenon marbles to Greece. ${ }^{90}$ Besides, even in these latter countries, archaeologists, museum curators and other professionals in the heritage sector often support claims for the return of cultural objects to the country or community of origin. They also react strongly against excessive commoditization of cultural heritage, as in the recent case in France, where the government was accused of exploiting patrimony for trade and diplomacy, on the occasion of a bilateral agreement concerning the opening of a branch of the Louvre in Abu Dhabi. ${ }^{91}$

A view which is often put forward (notably expressed by John Henry Merryman, Professor at the Stanford Law School) opposes 'cultural internationalism' to the 'cultural nationalism'92 of Greece and many other source countries, supported, in this binary approach, by UNESCO and archaeologists of the market countries, who depend on host nations for their research. In the view of 'cultural internationalism', generally invoked by art dealers, auction houses, private collectors and many major museum directors, cultural objects belonging to any people are the 'cultural heritage of all mankind', and what matters most is their preservation and accessibility for study, education and enjoyment, regardless of the place where they are situated. In parallel, the liberalization - within certain limits - of the international trade in cultural property and the channelling of surplus or redundant antiquities and other cultural items on to the free market - seen as capable of reducing the extent of the black market, while providing an income to the source nations - are regarded as necessary.

However, this approach would seem somewhat hypocritical, insofar as it does not lead to a fair distribution of antiquities and cultural objects in general (and, indeed, on this logic, why not of other material resources as well?) throughout the world, but to a one-way flow from less developed or from formerly colonized countries to wealthier ones, so that it ends up looking more like 'cultural imperialism'. ${ }^{93}$ At the same time, this way of thinking justifies the retention, even today, of cultural objects derived from different regions of the world by the so-called universal museums of the great metropolitan centres of the West, ${ }^{94}$ which have acquired them in other eras by questionable means and with the aim of confirming the cultural superiority of their nations. Seen in this light, the concept of 'universal' or 'world' museum reflects a colonialist - and, in the last analysis, nationalist - rather than an internationalist attitude.

It is worth noting, furthermore, that the release from source countries of surplus antiquities or of objects of minor importance on to the legitimate market does not seem to suffice to discourage illicit trafficking and the destruction of archaeological sites, since it is doubtful whether these are interesting enough to satisfy the demand. A significant and undeniable fact is that trading in art and antiquities remains the only major sector of international trade where secrecy prevails as to the provenance of the acquisitions. ${ }^{95}$

The central question around which the whole debate revolves is who owns antiquities, or, more generally cultural heritage. Before this issue is addressed in greater detail, it is tempting to cite some extracts from the debates held in the Greek Parliament in 1882 relating to the ceding to Germany of duplicates from the finds at Olympia. ${ }^{96}$ In the view of Pavlos Kalligas, 'Those who are in a position to appreciate the perfection of this plastic art and of the plastic power of the Greek mind, are those who enjoy as their own property all the antiquities; those who think that they possess this property do not partake of the enjoyment of it, they have only the material '. According to Ioannis Messinezis, 'the works of ancient art [...] are the works of the whole of humanity. [...] The antiquities are not our works, but works of people who are departed [...], of our forefathers and scattered over all the earth, they benefit us'. Stephanos Dragoumis, for his part, began by saying that the antiquities 'are indissolubly linked with the history of the country of Greece; it is only in the place where [...] they were made that they are able to receive the appropriate appreciation from science'; and he concluded that 'we owe 
to these [the antiquities] every care, not only because they are ancestral heirlooms, but also because we are regarded as appointed trustees of them, so that we can make them available for study to all the civilized world'.

So does archaeological, or, more generally, cultural heritage belong to mankind as a whole, or is the notion of universal cultural heritage a-historical, ${ }^{97}$ given that 'while cultural treasures may generate universal inspiration and appreciation, they are not universally created nor can there be international possession', as has been aptly observed? ${ }^{98}$ Although the concepts of 'common cultural heritage' or 'world heritage', used in UNESCO instruments, are not yet precise enough, it is apparent that they refer not to ownership but to the principle of collective responsibility for the protection and transmission of essential cultural legacies to future generations.

Does cultural heritage belong to a nation or to a state, entities which are ceasing to coincide in the global context? Does it belong to a national or ethnic community which invokes a relationship of descent and cultural continuity, or does it belong to the communities which come together in the territory where the material remains are situated? For example, does it belong to the Greeks in general, including the Greeks of the diaspora, as the law of 1834 proclaimed, or to the citizens of the country, to whom the law of 2002 makes reference, or, more broadly, to its residents? Included in the latter are not only the minorities but also the immigrants who live in the country, and, in a multicultural society, their participation, and,

\section{ABBREVIATION}

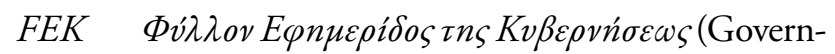
ment Gazette).

Notes

\section{FEK A' 158.}

2. FEK $\mathrm{A}^{\prime} 153$. For a detailed analysis of this law, which goes beyond the scope of the present paper, see the contributions included in Trova 2004.

3. Tsoukalas 1995, 299.

4. Korais 1964 [1807]. See also Kokkou 1977, 28-31. more generally, the participation of the local populations, in the definition of the heritage which is judged deserving of protection, in its management and enjoyment, is an issue worth examining.

Does cultural heritage belong to the specialists, the scholars, such as the archaeologists, who explore and study it? It is worth recalling here the questionable - and illegal - practice of the indefinite tying down of unpublished archaeological finds in Greece, by invoking exclusive rights of publication, by the archaeologist who discovered them or to whose administrative competence they are subject, or by their relatives. ${ }^{99}$

Or, finally, does nobody 'own' cultural heritage, at least not exclusively, since nobody has an exclusive right to its production or its interpretation? On the other hand, can we speak about one single national, or generally collective, cultural heritage, fixed, bounded and homogeneous, to be preserved and transmitted to future generations, or does each of us inherit multiple and overlapping cultural legacies, since the concepts of cultural heritage and of identity are open, dynamic and evolving?

In any event, as has been pointed out: 'Every legacy is distinctive, to be sure. But realizing our heritage problems are not unique makes them more bearable, even soluble.' ${ }^{100}$

Daphne Voudouri
Department of Communication, Media and Culture
Panteion University
dvoud@panteion.gr

Daphne Voudouri

Department of Communication, Media and Culture

dvoud@panteion.gr

5. Decree of Grigorios Dikaios (Papaflessas) of 10 February

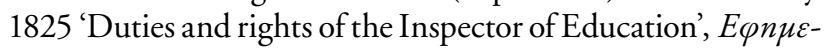

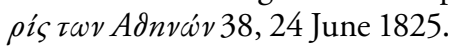

6. Article XVIII of the Resolution of the Third National Assembly 'On the organization of the Administration of the Greek State' of 1 May 1827 (reproduced in Protopsaltis 1967, 30) laid down that 'it shall be the duty of the Governor to take 
care that Antiquities shall not be sold or conveyed outside the State'.

\section{Makriyannis 1947, II 63.}

8. Xth Resolution of the Third National Assembly 'On the prohibition of the exportation outside the State of the monuments of antiquity' of 2 August 1829 (Protopsaltis 1967, 94). It is, however, also worth mentioning Kapodistrias' circular to the Provisional Commissioners in the Aegean of 12 May 1828, in which he called upon them to be vigilant in seeing that antiquities were not exported from the country and were ceded preferably to the government (Protopsaltis 1967, 39).

\section{Cf. Kalpaxis 1990, 22.}

10. He estimated that 'by ceding these [antiquities], Greece may obtain reciprocally from the governments to whom they belong objects which are valuable and necessary in common education establishments: e.g., books, astronomy, geodesy instruments, patterns of machinery, etc.' (Protopsaltis 1967, 93).

11. Resolution of the Governor No. 49 of 21 October 1829,

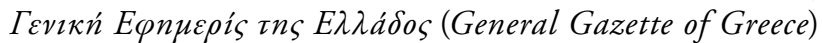
77, 16 November 1829. In a circular from the Provisional Commissioner of Elis, Panayiotis Anagnostopoulos, from the same period, concerning the protection of antiquities, the ban on selling them and the enrichment of the Museum (Circular No. 73 of 7 October 1829, Protopsaltis 1967, 107-9), the special symbolic value that antiquities held for modern Greeks is graphically expressed: 'These stir the spirit of the modern Hellenes to imitate and call to mind the brilliance and glory of their ancestors. They bring great honour to the nation. Honoured by wise Europe and sought after day by day by travellers, they make manifest their value, and it is as if they were saying to the Hellenes: "You must not undervalue the relics of your ancestors! They have assisted you and it is your duty to respect them, because they are sacred and are your possessions and are a part of your dignity and honour."

12. Article 2 of the Royal Decree of 3/15 April 1833, FEK 14.

13. Law of 10/22 May 1834 'On scientific and technological collections, on the discovery and conservation of antiquities and the use thereof', FEK 22, Article 76. See the historical data contained in Prott \& O'Keefe 1984, 31-71; Prott \& O'Keefe 1989, 453-64; Phelan 1998, which show that comprehensive national laws on antiquities date from after 1834. Even in Italy, the first major national protective legislation was enacted in 1902 , long after unification, although the earliest legislation for the protection of ancient monuments is considered to be that of the Papal State of Rome from the 15th c. It is also interesting to note that the law of 1834 systematically regulated not only matters concerning the status of antiquities but also those concerning the relevant state service and the museums.

14. Article 77, in conjunction with Articles 75 and 79. Selling such antiquities or trading in them after notification was also permitted (Article 78).

15. Maurer 1976 [1835], 551. More specifically, the edict promulgated by Cardinal Pacca in April 1820.

16. Articles 62-64.
17. See the transcripts of the relevant parliamentary de-

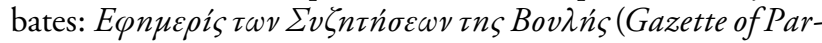
liamentary Proceedings), 30 June 1899, 1207.

18. Circular No. 11538 of 30 August 1899 'Instructions concerning the implementation of Law 2646 on antiquities', reproduced in General Ephorate of Antiquities 1905, 346-50. It is also worth noting that in a previous circular concerning the implementation of the law of 1834 (Circular No. 874 of 4 February 1865 from the Minister for Church Affairs and Public Education A.H. Lontos, General Ephorate of Antiquities 1886, 50-51), it had been pointed out that those who dug without a permit and sold the antiquities they found to foreigners 'not only deprive the national Museum of the precious heirlooms of our ancestors but bring disgrace upon the nation among those to whom they sell them, as trading in the relics of its forebears - those very relics which both aroused in it the sense of its own nationality and brought about the acquisition of its freedom.'

19. See, especially, Lowenthal 1988; Morris 1994.

20. Law 5351 'On antiquities', codified by the Presidential Decree of 9/24 August 1932, FEK A' 275. For a further analysis of this legislation, which was in force until 2002, see Doris 1985; Voudouri 1992.

21. For instance, in the Ottoman Empire a decree of 1906 declared for the first time that all antiquities found in or on public or private lands were state property, while previously, under a decree of 1884, one half of any antiquities fortuitously discovered on private land were given to the landowner (Ozel \& Karadayi $1998,2-5)$. As early as 1887 , however, a Mexican law declared all archaeological monuments to be state property, but it seems that this declaration was not sufficiently clear and did not apply to movable objects (Sànchez Cordero 2004, 303-6). See also, more generally, Prott \& O’Keefe 1984, 34-71; 188-202.

22. As has been accepted by the consistent case law of the Court of Cassation (Areios Pagos), in interpreting the provisions of Articles 1 and 2 of Codified Law 5351/1932, which are derived from Law 2646/1899 (Judgments 407/1972 [Plenum]; 673/1973; 305/1990; 1031/1991; 558/1998 etc.). This is provided also by Law 3028/2002 (Articles $7 \S 1$, and $21 \S$ 1 ), although the notion of antiquities or 'ancient monuments' has now been extended to cover cultural objects dating from prehistoric times up to 1830 (Article 2, sub-para. b, aa').

23. In these efforts, against which some voices of protest were raised, the Archaeological Society at Athens (founded in 1837) played a leading role. The object of the biggest operation of socalled clearing of the post-classical remains was the Athenian Acropolis. See on this issue, among others, Kokkou 1977, 11216; McNeal 1991.

24. Article 111 of the law of 1834; Royal Decree of 1/19 December 1837, General Ephorate of Antiquities 1886, 33. See Voudouri 2003, 61-63.

25. Articles 12, 14, 25 and 26.

26. Article 22.

27. Article 20. 
28. As can be seen from the transcripts of parliamentary

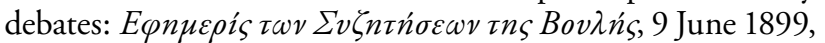
587 and 30 June 1899, 1205-7.

29. More specifically, according to Article 24 of the law, the exchange was possible, by ministerial decision, in the case of antiquities declared unanimously by the Archaeological Committee (the supreme collective organ for the administration of antiquities, the equivalent of today's Central Archaeological Council) surplus to the requirements of the museums.

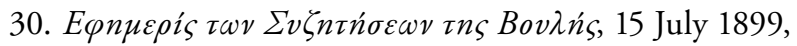
1583 and 1593-1594. On the other hand, there was provision for the sale of redundant antiquities in the archaeological legislation of the Cretan State of the same period; this also provided for state ownership of antiquities (Act 24 of 18/21 June 1899

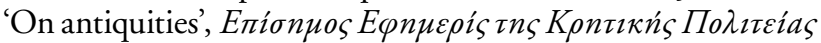
[Official Gazette of the Cretan State] A' 51, Articles 19 and 1, respectively).

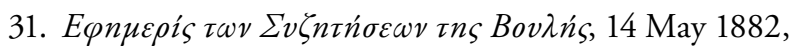
776-87. The earlier ceding to the USA of a marble plinth from the Parthenon which was to be built into the Washington Monument, after an honorific inscription had been carved on it, by virtue of the Royal Decree of 4/10.6.1854 (FEK 16), could also be mentioned.

32. Article 6 of the convention signed in Athens on 13/25 April 1874 and ratified by Law 541/1875, FEK 59. In contrast, the Greek-French agreement on the excavations at Delphi (concluded in Athens on 23 January/4 February 1887 and ratified by Law 1974/1891, FEK A' 126) made no such provision. In any case, the Greek-German convention of 1874 is considered to be the earliest convention recognizing state property in archaeologfical finds.

33. Law 491/1914, FEK A' 245, amended by Article 6 of Law 4823/1930, FEKA' 245.

34. Thus, in 1914, charges for admittance were also introduced, by Law 464 (FEK A' 373) at certain archaeological museums, the list of which was expanded by the provisions of Law 4823/1930, which at the same time laid down measures for the attraction of groups of foreign visitors. As early as 1885 provision was made for the possibility of selling redundant material from excavations for the support of a special fund for the museums (Royal Decree of 26 November 1885, FEK A' 113, Articles 9-10), while at an earlier date the assignment of the price realized from the sale of material from excavations or the material itself to the Athens Archaeological Society was provided for (Law 612/1861, FEK 15).

35. Article $30 \S 2$.

36. FEKA' 25. See also, in this connection, Pantos 1992, 65.

37. Reprinted in Karouzos 1995, 238-47 (first publication: To Vima, 12 and 14 September 1948).

38. Royal Decree of 11 August 1899, 'On the declaration of importation and exportation of antiquities' (FEK A' 179), Article 3.

39. Ministry of Culture 1998, 78-98. See also Tiverios 1998.
40. More specifically, by a decision of the Minister of Culture (following a recommendation of the Service and an opinion of the Council), the exchange of published movable - ancient or modern - monuments which belong to the state and are in its possession may be allowed on condition that they are not of particular significance for the country's cultural heritage, that they are not needed for the completion of collections of other museums in the country and that the unity of important collections is not affected in return for cultural objects of equal importance, which belong to other states or foreign legal persons of non-profit character and which are of particular significance for the collections of the public museums of the country (Article $25 \S 2$ ).

41. Chiefly because it requires a prior administrative licence for possession (Article 23).

42. See, e.g., I Kathimerini, 5 June 2002.

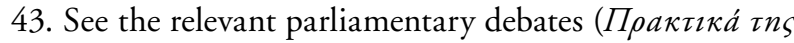
Bovגn's, 11 and 12 June 2002).

44. Petrakos 2003, 105.

45. Legislative Decrees of 9 December 1922 (FEK A' 232) and of 26 April 1926 (FEK A' 144). The loan was made on condition they were returned within three years, but in the end, they were not returned until much later.

46. Law 3599/1930 (FEK A' 138), Articles 13 § 2, and 12, $\S 1$, respectively. A similar provision regarding the loan of its works to museums and their exportation for exhibitions was subsequently also included in the law establishing the Goulandris Foundation Museum of Cycladic Art (Article $13 \S 2$ of Law 1610/1986, FEK A' 89).

47. Article 19. The re-exportation of legally imported antiquities was free, under Article 18.

48. 'On the amendment of the provisions in force on antiquities and on the Archaeological Council', FEKA' 214, Article 1.

49. Under Article $1 \S 7$ of Law 2412/1996 (FEK A' 123), a simple decision from the Minister of Culture was required.

50. For the New York World Fair (1939/1940), where they were 'trapped' because of the war, and returned in 1948 .

51. This was the Kore 680 from the Acropolis Museum, which was sent to Japan for the EXPO ' 70 commercial exhibition in Osaka.

52. On the loans of antiquities abroad, see especially Petrakos 1982, 79-92; Simopoulos 1997, 406-20.

\section{I Kathimerini, 11 May 1924.}

54. Reprinted in Karouzos 1995, 315-17 (317); first published in 1952.

55. Act 68 of 15 November 1963, reproduced in Petrakos 1982, 81-84.

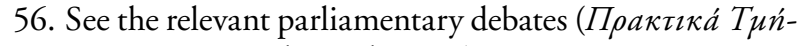

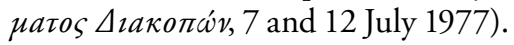

57. See Hamilakis \& Yalouri 1996, 125-27. 
58. Thus, for example, Vasileios Petrakos not only held that 'exhibitions abroad [...] from 1978 onwards have been the chief cause of the misfortunes in the organization and academic development of the discipline of archaeology in this country', but also maintained that 'those nations which do not have such art, like the Romans, or the modern European nations which have torn apart countries such as Greece regard our antiquities as a

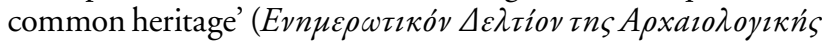
Eqaipzias 17, October 1991, 103; 127). For his part, the writer Kyriakos Simopoulos described the sending of antiquities for exhibition abroad as 'an unpatriotic act [on the part of the political authorities] which is tantamount to national unworthiness', and insisted that the antiquities should always remain in their birthplace, because 'artistic treasures are identified with the specific place and the specific people, particularly in the case of a people with racial and cultural continuity through time' (Simopoulos 1997, 407 and 18 respectively). On this debate see also $O$ Mév $\tau \omega \rho$ 20, May 1992, 18-89.

59. For a list of the exhibitions of antiquities held abroad up to 2000, see $O M \dot{v} v \tau \omega \rho$ 71, 2004, 54-56. For a general presentation on the organization of temporary exhibitions by the Ministry of Culture, see Divari-Valakou 2006.

60. For instance, the Minister of Culture Constantine Trypanis pointed out in Parliament, during the debate on the above draft law, that the exhibitions of antiquities abroad which were planned would also include antiquities from Cyprus, so as to make apparent 'yet again the unity of Greece and Cyprus - the historical unity and that of art - and in general the Greekness of the Great Island and, consequently, the sound founda-

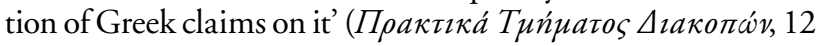
July 1977,141$)$.

61. It is worth noting that proof of the 'Greekness of the Aegean region since ancient times' was used as an argument in favour of the establishment of the Goulandris Museum of Cycladic Art, as can be seen from the explanatory report of 28 May 1986 on Law 1610/1986, which was signed by the Minister of Culture Melina Mercouri and the Minister of Finance Dimitrios Tsovolas.

62. As Kostas Kotsakis points out, in recent decades the main project of archaeological research in Greece is to offer material evidence concerning the ethnic identity of the ancient Macedonians and the Hellenic character of their culture, an issue which is also subtly amplified by museum exhibitions organized abroad (Kotsakis 1998, 56).

63. See the relevant statements of the Minister of Culture Tzanis Tzanetakis on the government's plan to send antiquities to the Olympic Museum in Lausanne, to the effect that 'we must show the continuity of our culture, in order to discourage any Duroselle' (I Kathimerini, 5 July 1991) and that 'this is a national battle in which we have an inexhaustible cultural armoury and superiority, from the most ancient of times to the present. In an age when frontiers are being abolished, when earth-shattering events are taking place around us, the promotion of our national identity is a matter of major political responsibility. Can the contrary opinion be the result of patriotism?' (I Kathimerini, 19 July 1991).
64. Temporary archaeological exhibitions on subjects related to the Olympic Games have been organized by the Greek Ministry of Culture mainly in connection with the holding of the Games in Athens, but also more generally, 'since they draw attention to the Greek origins of the Olympic Games' (DivariValakou 2006, 266).

65. For a comment on travelling museum exhibitions of the period 1979-1993, see Mouliou 1996.

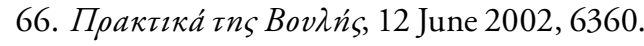

67. Article $25 \S 1$ reads as follows: 'The loan of published movable monuments, which belong to the State and are in its possession, to museums or educational organizations for exhibition or educational purposes may be allowed in exceptional cases upon decision of the Minister of Culture, following a recommendation of the Service and an opinion of the Council. The loan to museums shall take place on condition of reciprocity. The loan for educational purposes may be allowed only if the monuments are not of particular significance for the country's cultural heritage. The loan shall be agreed for a definite period of time, which shall not exceed five (5) years and may be renewed under the same procedure'.

68. Article $34 \S 11$ reads as follows: 'By a decision of the Minister of Culture, following an opinion of the Council, the temporary export of monuments may be allowed for their exhibition in museums or similar institutions, on condition that the necessary guarantees are provided for their safe transport, exhibition and return and after the significance of the exhibition for the promotion of the country's cultural heritage or eventual reciprocity has been assessed, or for conservation, educational or research purposes, provided that equivalent guarantees are offered and the relevant conservation work and study cannot take place in Greece.' It is also worth mentioning that, according to Article $29 \S 2$ of the law, the holders of movable antiquities belonging to the state shall make them available to the State Archaeological Service for a reasonable time, if so requested, for their exhibition within or outside Greek territory.

69. The re-exportation of monuments of foreign origin which have been certified as having been imported legally within the last 50 years is permitted (Article $34 \S 6$ ).

70. See, for example, I Kathimerini, 18 March 2007; To Vima, 1 April 2007.

71. See, in particular, the Preamble to the 1970 UNESCO Convention on the means of prohibiting and preventing the illicit import, export and transfer of ownership of cultural property (reproduced in UNESCO 1985, 57); Preamble to the 1995 UNIDROIT Convention on stolen or illegally exported cultural objects (34 International Legal Materials, 1322); Article 8 § (i) of the 1992 European Convention on the protection of the archaeological heritage (revised) (European Treaty Series 143); 1976 UNESCO Recommendation concerning the international exchange of cultural property (reproduced in UNESCO 1985, 181); 1978 UNESCO Recommendation for the protection of movable cultural property (UNESCO 1985, 209); ICOM Code of Ethics for Museums (adopted in 1986 and amended in 2001 and in $2004, \S 3.6$, available online at http://icom.museum/ 
ethics.html); Berlin Declaration 1988 by the International Congress for Classical Archaeology 'Loans and Acquisitions of Archaeological Objects by Museums' (reproduced in O'Keefe 1997, 121).

72. See, especially, Palmer 1997.

73. See, e.g., Palmer 2000. It is within this context that the recent case of El Greco's painting View from Mount Sinai, from the Herakleion Historical Museum, is to be seen. The painting, displayed in a Metropolitan Museum exhibition in 2003, became the object of a claim by a Swiss citizen, who maintained that it had been confiscated by the Nazis. It was, however, protected by anti-seizure legislation during the loan (Eleftherotypia, 24 January 2004).

74. As stated in the Preamble to the 1970 UNESCO Convention.

75. See, among others, Wallis 1994.

76. The case of the exhibition of Minoan antiquities from the private collection of Elie Borowsky, together with antiquities from Greek museums, in Karlsruhe in 2001 (e.g. I Kathimerini, 1 and 7 June 2001) is a reminder of this. See, more generally on this issue, Renfrew 1999.

77. These agreements have been concluded for the implementation of Article 9 of the 1970 Convention, in accordance with the United States Convention on Cultural Property Implementation Act of 1983 (19 U.S.C. 2601). The agreement with Italy was signed on 19 January 2001, extended and amended on 19 January 2006. The agreement with Cyprus was signed on 16 July 2006 and was extended and amended on 16 July 2007. The text of these agreements and further information on this issue are available online at http://exchanges.state.gov/culprop.

78. See the statement issued by the Metropolitan Museum of Art on its agreement with the Italian Ministry of Culture on 21 February 2006 (http://www.metmuseum.org/press_room/ full_release.asp?prid, last accessed 10 October 2007); The Independent, 21 February 2006. On this agreement and on two similar bilateral agreements concluded between Italy and two other major American museums, the Museum of Fine Arts in Boston (September 2006) and the J. Paul Getty Museum in Malibu (August 2007), see Gill \& Chippindale 2007.

79. See the joint statement issued by the Greek Ministry of Culture and the J.Paul Getty Trust on 11 December 2006 (http://www.getty.edu/news/press/center/statement06_getty_ greek_joint_release_121106.html; http://press.culture.gr, last accessed 10 October 2007).

80. See, further, Voudouri 2004.

81. Article $31 \S 5$. According to the explanatory report on the draft law, by its provisions 'the model of the collector who has dealings with clandestine excavators and illicit traders in antiquities is precluded'. It is worth noting, however, the rather widespread view among archaeologists that 'the only good collector is an ex-collector' (Renfrew 1999, 44).

82. See Articles $33 \S 1,64$ and 65.

83. Articles $45 \S 9,31, \S 6$, and $32 \S 6$, respectively.

\section{Article $33 \S 3$.}

85. Archaeological museums - including Byzantine museums - in Greece are, except in one or two cases (the Benaki Museum, which is not purely archaeological, and the N.P. Goulandris Foundation - Museum of Cycladic Art), stateowned, and, moreover, incorporated into the legal person of the state. In contrast, the overwhelming majority of the museums of other kinds belong to local government bodies or other public entities or to private non-profit organizations, while those few that are state run have, in principle, their own legal personality. See, further, Voudouri 2003.

86. To use an expression of Constantinos Tsoukalas (Tsoukalas 1999, 411). On the sacralization of antiquities in Modern Greece, see also Hamilakis \& Yalouri 1999; Hamilakis 2007.

87. Lowenthal 1998, 244.

88. See, among many others, Trigger 1989; Kohl \& Fawcett 1995; Diaz-Andreu \& Champion 1996; Meskell 1998.

89. See, e.g., Lewis 1995.

90. http://www.britishmuseum.org/the_museum/ news_and_debate/debate/parthenon_sculptures/facts_and_ figures.aspx, last accessed 10 October 2007.

91. See, for example, Le Monde Diplomatique, February 2007; Le Monde, 8 Mars 2007; USA Today, 9 August 2007.

92. See Merryman 2000, which contains most of his articles on this subject, published during the period 1985-1998, as well as some critical comments on his proposals; Merryman 2005; Merryman 2006. On the relevant current debate, see also Niedzielski-Eichner 2005; Hallman 2005; Prott 2005; Lowenthal 2005.

93. See, in particular, Prott 2005, 228; Koumantos 1990, 163.

94. See the 'Declaration on the importance and value of universal museums', signed by 18 directors of the world's leading museums in December 2002, in which, citing the example of the sculpture of classical Greece to illustrate the role of universal museums in highlighting its 'significance for mankind as a whole', they oppose the repatriation of 'objects which have belonged to museum collections for many years' (text reproduced in Lewis 2006, 381-82). On the concept of universal museum, see also the article of the Director of the British Museum, MacGregor 2004.

95. Cf. Bator 1982, 360. On the complex issues relating to the international trade in antiquities, see also Tubb 1995; Briat \& Freedberg 1996; O’Keefe 1997.

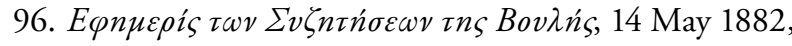
776-87.

97. See also Warren 1993.

98. Greenfield 1995, 312.

99. See further Voudouri 2003, 206-29.

100. Lowenthal 1998, 249. 


\section{REFERENCES}

Bator P. 1982: An essay on the international trade in art, Stanford Law Review 34, 275-384.

Briat M. \& Freedberg J. (eds) 1996: International Sales of Works of Art, V: Legal Aspects of International Trade in Art (Paris and The Hague).

Diaz-Andreu M. \& Champion T. (eds) 1996: Nationalism and Archaeology in Europe (London).

Divari-Valakou N. 2006: The Organisation of Temporary Exhibitions by the Departments of the General Directorate of Antiquities and Cultural Heritage, in: Enhancement and Promotion of Cultural Heritage. (Athens) 263-65.

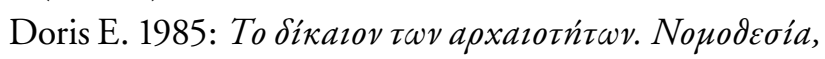

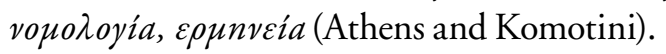

General Ephorate of Antiquities 1886: $\Sigma v \lambda \lambda$ oyń a $\rho x a \imath o \lambda o-$

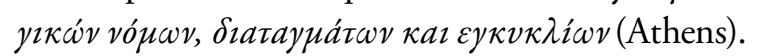

General Ephorate of Antiquities 1905: $\Sigma v \lambda \lambda$ oyń a $\rho x a \imath o-$

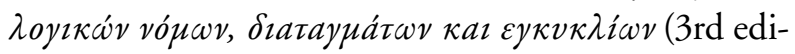
tion; Athens).

Gill D. \& Chippindale C. 2007: From Malibu to Rome: further developments on the return of antiquities, International Journal of Cultural Property 14, 205-40.

Greenfield J. 1995: The Return of Cultural Treasures (2nd edition; Cambridge).

Hamilakis Y. 2007: The Nation and its Ruins: Antiquity, Archaeology and National Imagination in Greece (Oxford).

Hamilakis Y. \& Yalouri E. 1996: Antiquities as symbolic capital in modern Greek society, Antiquity 70, 117-29.

Hamilakis Y. \& Yalouri, E. 1999: Sacralising the past: cults of archaeology in modern Greece, Archaeological Dialogues 6, 115-60.

Hallman R. 2005: Museums and cultural property: a retreat from the internationalist approach, International Journal of Cultural Property 12, 201-23.

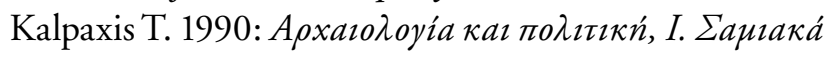

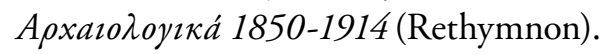

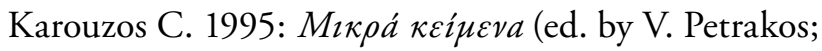
Athens).

Kohl P.L \& Fawcett C. (eds.) 1995: Nationalism, Politics and the Practice of Archaeology (Cambridge).

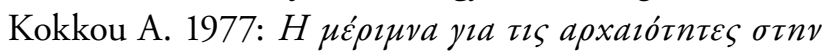

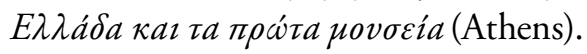

Koumantos G. 1990: Réflexions préalables sur la protection internationale des biens culturels, in: Brem E. et al. (eds), Festschrift zum 65.Geburtstag von Mario Pedrazzini (Bern) 159-71.

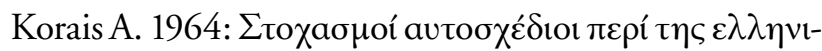

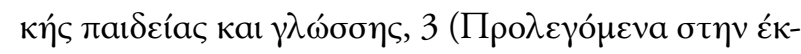

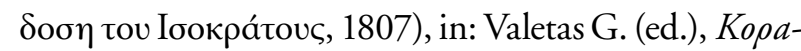

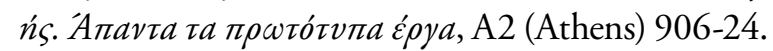

Kotsakis K. 1998: The Past is Ours: images of Greek Macedonia, in: Meskell L. (ed.), Archaeology under Fire: Nationalism, Politics and Heritage in the Eastern Mediterranean and Middle East (London and New York) 44-67.

Lewis G. 1995: Attitudes to disposal from museum collections in: Fahy A. (ed.), Collection Management(London and New York) 172-81.

Lewis G. 2006: The 'Universal Museum': A case of special pleading?, in: Hofman B. (ed.), Art and Cultural Heritage: Law, Policy, and Practice (Cambridge) 379-85.

Lowenthal D. 1988: Classical antiquities as national and global heritage, Antiquity 62, 726-35.

Lowenthal D. 1998: The Heritage Crusade and the Spoils of History (Cambridge).

Lowenthal D. 2005: Why sanctions seldom work: reflections on cultural property internationalism, International Journal of Cultural Property 12, 395-423.

MacGregor N. 2004: The whole world in our hands, The Guardian, 24 July.

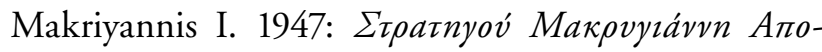

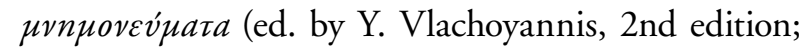
Athens).

Maurer G.L. 1976: O $\varepsilon \lambda \lambda n v \imath \kappa o ́ s \lambda a o ́ s(e d . b y$ T. Vournas; Athens) [Das Griechische Volk (1835)].

McNeal R. 1991: Archaeology and the destruction of the later Athens Acropolis, Antiquity 65, 49-63.

Meskell L. (ed.) 1998: Archaeology under Fire: Nationalism, Politics and Heritage in the Eastern Mediterranean and Middle East (London and New York).

Merryman J.H. 2000: Talking about the Elgin Marbles: Critical Essays on Cultural Property, Art and Law (The Hague).

Merryman J.H. 2005: Cultural property internationalism, International Journal of Cultural Property 12, 11-39.

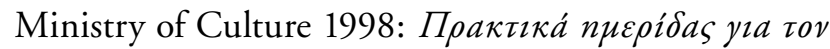

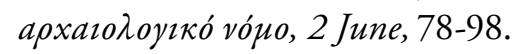

Morris I. 1994: Archaeologies of Greece, in: Morris I. (ed.), Classical Greece: Ancient Histories and Modern 
Archaeologies (Cambridge) 8-47.

Mouliou M. 1996: Ancient Greece, its classical heritage and the modern Greeks: aspects of nationalism in museum exhibitions, in: Atkinson J.A. et al. (eds), Nationalism and Archaeology (Glasgow) 174-99.

Niedzielski-Eichner N. 2005: Art historians and cultural property internationalism, International Journal of Cultural Property 12, 183-200.

O'Keefe P.J. 1997: Trade in Antiquities: Reducing Destruction and Theft (Paris and London).

Ozel S. \& Karadayi, A. 1998: Laws regarding the protection of the cultural heritage of Turkey, in: Phelan M. (ed.), The Law of Cultural Property and Natural Heritage: Protection, Transfer and Access (Evanston) Ch. 20.

Palmer N. 1997: Art Loans(London).

Palmer N. 2000: Museums and the Holocaust: Law, Principles and Practice (London).

Pantos P. 1992: Greece and Greek legislation about antiquities, Atti dei Convegni Lincei 93, 59-74.

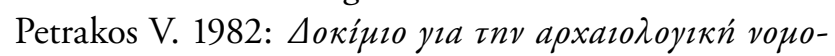
devia (Athens).

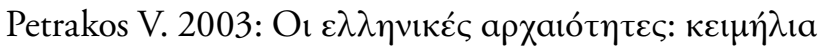

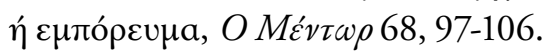

Phelan M. (ed.) 1998: The Law of Cultural Property and Natural Heritage: Protection, Transfer and Access (Evanston).

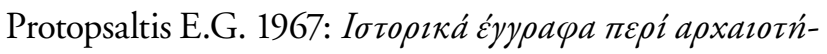

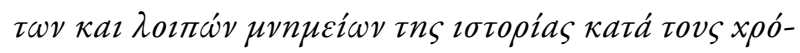

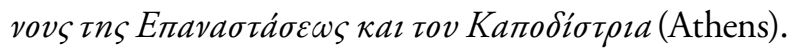

Prott, L.V. \& O'Keefe, P.J. 1984: Law and the Cultural Heritage, I: Discovery and Excavation (Abington).

Prott L.V. \& O'Keefe P.J. 1989: Law and the Cultural Heritage III: Movement (London and Edinburgh).

Prott L.V. 2005: The international movement of cultural objects, International Journal of Cultural Property 12, 225-48.

Renfrew C. 1999: Loot, Legitimacy and Ownership: the Ethical Crisis in Archaeology (Amsterdam).

Sànchez Cordero J. 2004: Les biens culturels précolombi- ens. Leur protection juridique (Paris).

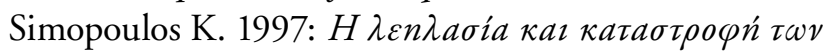

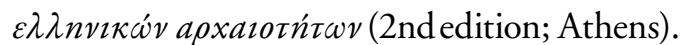

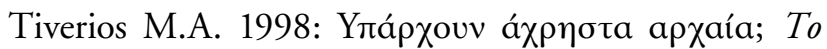
Vima, 5 July.

Trigger B.C. 1989: A History of Archaeological Thought (Cambridge).

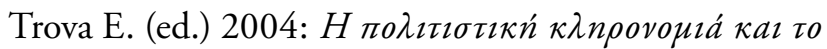
Sikaıo (Athens and Thessaloniki).

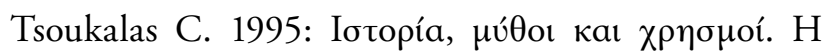

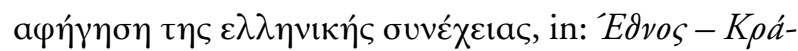

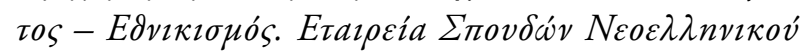

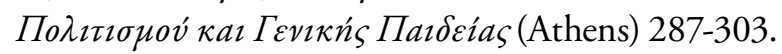

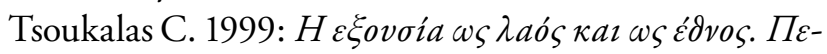

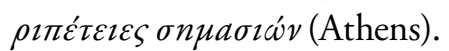

Tubb K.W. (ed.) 1995: Antiquities: Trade or betrayed. Legal, Ethical and Conservation Issues (London).

UNESCO 1985: Conventions and Recommendations of UNESCO concerning the Protection of the Cultural Heritage (2nd edition; Paris).

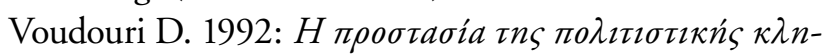

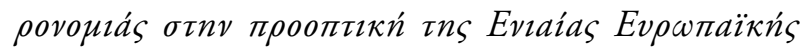
Ayoóás(Athens).

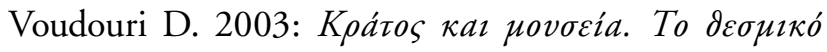

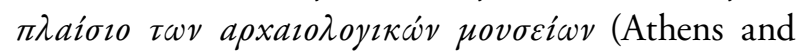
Thessaloniki).

Voudouri D. 2004: O véos vó

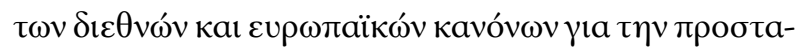

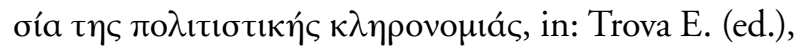

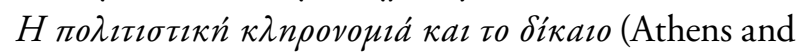
Thessaloniki) 25-41.

Wallis B. 1994: Selling nations: international exhibitions and cultural diplomacy, in: Sherman D. \& Rogoff I. (eds), Museum Culture: Histories, Discourses, Spectacles (London) 265-81.

Warren K. 1993: A philosophical perspective on the ethics and resolution of cultural property issues, in: Messenger P.M. (ed.), The Ethics of Collecting Cultural Property: Whose Culture? Whose Property? (2nd edition; Albuquerque) 1-26. 
